Residential landscape as a predictor of psychosocial stress in the life course from childhood to adolescence

Peer-reviewed author version

Van Aart, Carola J. C.; Michels, Nathalie; Sioen, Isabelle; De Decker, Annelies; BIJNENS, Esmee; JANSSEN, Bram; De Henauw, Stefaan \& NAWROT, Tim (2018) Residential landscape as a predictor of psychosocial stress in the life course from childhood to adolescence. In: Environment international, 120, p. 456-463.

DOI: 10.1016/j.envint.2018.08.028

Handle: http://hdl.handle.net/1942/28753 


\section{Residential landscape as a predictor of psychosocial stress in the life course from childhood to adolescence}

Carola J.C. Van Aart ${ }^{1}$, Nathalie Michels ${ }^{1}$, Isabelle Sioen ${ }^{1,2}$, Annelies De Decker ${ }^{1}$, Esmee M. Bijnens $^{3}$, Bram G. Janssen 3 , Stefaan De Henauw ${ }^{1,4}$, Tim S. Nawrot ${ }^{3,5}$

${ }^{1}$ Department of Public Health, Ghent University, Corneel Heymanslaan 10 4K3, 9000 Ghent, Belgium

${ }^{2}$ Department of Food Safety and Food Quality, Ghent University, Coupure Links 653, 9000 Ghent, Belgium

${ }^{3}$ Centre for Environmental Sciences, Hasselt University, Martelarenlaan 43, 3500 Hasselt, Belgium

${ }^{4}$ Department of Health Sciences, Vesalius, University College Ghent, Keramiekstraat 80, 9000 Ghent, Belgium

${ }^{5}$ Department of Public Health and Primary Care, Leuven University, Kapucijnenvoer 35 blok d, 3000 Leuven, Belgium

\section{Corresponding author}

Van Aart CJC, MSc, Department of Public Health, Faculty of Medicine and Health Sciences, Ghent University, Corneel Heymanslaan 10 4K3, 9000 Ghent, Belgium. Phone: 00329332 3685. E-mail: Carola.vanAart@ugent.be 


\begin{abstract}
Background: The effects of residential landscape, i.e., land use and traffic, on psychosocial stress in children are unknown, even though childhood stress might negatively affect normal development. In a longitudinal study, we investigate whether the residential landscape predicts childhood psychosocial stress and whether associations are independent of noise and air pollution.
\end{abstract}

Methods: Belgian children aged 6.7-12.2 ( $N=172,50.9 \%$ boys) were followed for three years (20122015). Information on stress was obtained using standardized behavioral and emotional questionnaires and by a measure of hair cortisol. Residential landscape, including natural, agricultural, industrial, residential areas, and traffic, in a $100-\mathrm{m}$ to $5-\mathrm{km}$ radius around each child's home was characterized. Cross-sectional and longitudinal associations between psychosocial stress and the residential landscape were studied using linear regression and mixed models, while adjusting for age, sex, and parental socioeconomic status.

Results: Natural landscapes were positively associated with better emotional status (increased happiness and lower sadness, anxiousness, and total negative emotions, $\beta=0.14-0.17,95 \% \mathrm{Cl}=0.01-$ 0.30). Similarly, we observed an inverse association between residential and traffic density with hyperactivity problems $(\beta=0.13-0.18,95 \% \mathrm{Cl}=0.01-0.34)$. In longitudinal analyses, industrial area was a predictor of increases in negative emotions, while a natural landscape was for increases in happiness. Only the effect of natural landscape was partly explained by residential noise.

Conclusion: Residential greenness in proximity to a child's residence might result in a better childhood emotional status, whereas poorer emotional status and behavioral problems (hyperactivity problems) were seen with residential and industrial areas and increased traffic density in proximity to a child's home.

Keywords: Residential landscape, green space, psychosocial stress, children, adolescents 


\section{Introduction}

Exposure to nature has beneficial effects on human health, whereas decreased exposure to nature may result in poorer health. The literature shows that a lack of green environment might increase weight, type 2 diabetes, cardiovascular disease, anxiety disorders, and depression. ${ }^{1-6}$ Similar associations are also seen with urban environments, e.g., traffic and industrial areas, which could increase depressive symptoms and lower general psychological health. ${ }^{7,8}$ An explanation for these findings might be supported by the Biophilia hypothesis of E.O. Wilson, ${ }^{9}$ which suggests that humans have evolved to focus on life and lifelike processes (e.g., nature and plants). Ulrich's psychoevolutionary theory elaborates further on this, that exposure to nature might reduce stress. ${ }^{10}$

Thus, land use might have an influence on an individual's psychological state and psychosocial stress level. Psychosocial stress refers to a chronic state of psychological and/or social stressor load, which leads to prolonged activation of three highly integrated systems, i.e., the immune, nervous, and endocrine systems, with detrimental physiological consequences, such as cardiovascular and neurodegenerative disorders. ${ }^{11,12}$ The literature on adults shows, in correspondence with the psychoevolutionary theory, that green space could reduce stress. ${ }^{13-17}$

Despite the current knowledge that land use might influence psychosocial stress in adults, empirical evidence of this effect during childhood and adolescence is lacking, even though psychosocial stress at this age might be harmful for future health conditions. Therefore, we evaluated an affluent and densely populated society to determine whether different types of residential landscape, described by land use (semi-natural and forested areas, agricultural areas, industrial areas, and residential areas) and traffic (residential traffic density and proximity to major roads) impact psychological stress during the development of a human from child to (young) adolescent. We collected data over a three-year follow-up period from childhood to adolescence and measured both subjective and objective stress levels to address this association. To shed light on a possible pathway by which the residential landscape might affect psychosocial stress, we additionally investigated whether associations between the residential landscape and stress are independent of noise and air pollution. After all, the effect of residential landscape on psychosocial stress might be (1) directly by natural (green) elements creating visual/psychological stimulations and physical activity possibilities which can be reflected by land use but (2) also indirectly by noise and air pollution as a result of the land use and traffic. 


\section{Methods}

\subsection{Study population}

In 2015, 242 Belgian children and adolescents aged 9 to 15 years from the municipality of Aalter and its surroundings participated in the sixth wave of a large longitudinal study. The baseline survey was conducted in spring 2008, with follow-up surveys in spring 2010, 2011, 2012, 2013, and 2015, as part of different study projects. ${ }^{18,19}$ For the current article, we used data from 2012 onward because of incomplete stress questionnaires and address information before 2012. Children were included based on the availability of stress data, residential landscape, and parental socioeconomic data (parent with the highest achieved education based on the International Standard Classification of Education ${ }^{20}$ ) in 2015, as can be seen in the flow-chart in Figure 1. For the longitudinal analysis, we included children who did not move between 2012 and 2015. Children without stress data $(N=7)$ and socioeconomic status ( $N=11)$ were excluded, which resulted in 224 subjects in 2015 . The number of children with hair cortisol data $(N=153)$ is limited because this was an optional part of the survey, and sometimes the hair was not long enough for analyses. No differences in age, residential landscape, and stress were seen between children with and without hair cortisol data; however, included children were more often female and had a lower hyperactivity score. All children were Caucasian, except one of African origin. The study was conducted according to guidelines laid down in the Declaration of Helsinki, and the project protocol was approved by the Ethics Committee of the Ghent University Hospital. A written informed consent was obtained from the parents and a verbal assent from the children. In 2015, children older than 12 years also signed a written informed consent.

\subsection{Geographical area}

Study participants were from the municipality of Aalter and its surroundings, located approximately $20 \mathrm{~km}$ west of Ghent, Belgium, with a population density of 240.7 inhabitants per $\mathrm{km}^{2}$ in $2011 .{ }^{21}$ Location of study participants and the distribution of land-use indictors in this geographical area are shown in Supplemental Figure S1. Directly south of the city is a major motorway and to the north are primarily food processing industries (milk, meat), which are mainly small to middle sized. Most of the hinterland consists of agricultural areas with a majority of grassland and maize areal. Approximately $10 \mathrm{~km}$ north of Aalter is a small airport used by ultra-light aircrafts during the weekends.

\subsection{Psychosocial stress parameters}

Stress arises when the demands of a situation exceed an individual's ability to cope and resolve the problem, resulting in emotional and behavioral disturbances. ${ }^{22}$ Three stress-related tests were used to 
assess different aspects of a child's stress in 2012 and 2015. First, children were questioned about recent feelings of happiness, sadness, anger, and anxiousness using a 0-10 Likert scale, with 0 as the lowest score and 10 as the highest score. Total negative emotions were obtained by adding up the negative emotions: sadness, anger, and anxiousness. Second, parents filled in the Strength and Difficulties Questionnaire (SDQ) to assess behavioral problems during the past six months (reliability: ICC $=0.80$; concurrent validity: $r=0.70) .{ }^{23}$ The SDQ consists of 25 questions that can be divided into five subscales (each having five items): conduct problems, hyperactivity problems, emotional problems, peer relationship problems, and prosocial behavior. ${ }^{23}$ In addition, a general total difficulty score was calculated by adding up all subscales except the prosocial behavior scale (since this is a strength). Finally, hair cortisol was used as an objective stress biomarker (higher cortisol representing higher stress); however, it was only used in $2015 .{ }^{24} \mathrm{~A}$ hair strand with a diameter of 3-5 mm was cut close from the back of the scalp. Only the proximal $3 \mathrm{~cm}$ of the strand was analyzed, as this would reflect stress exposure during the last three months. Extraction and liquid chromatography coupled with tandem mass spectrometry was performed at the Laboratory for Hormonology, Ghent University Hospital, Belgium. For analysis on 15 mg of hair, inter-assay CV for cortisol is $10.8 \%$ with an LOQ of 1.6 $\mathrm{pg} / \mathrm{mg}$ hair. Detailed laboratory analyses are described elsewhere. ${ }^{25}$ None of the participants took systematic corticosteroids.

\subsection{Land use and residential proximity to traffic}

Residential addresses of the participating children and adolescents were geocoded. Semi-natural, forested, and agricultural areas (greenness) and residential and industrial areas in a 5000, 4000, 3000, $2000,1000,500,300$ and $100 \mathrm{~m}$ buffer from the residential address were estimated based on the European Coordination of Information on the Environment (CORINE database) land cover 2000 (European Environment Agency). The land-cover data is based on satellite data and is divided in 44 classes. It is presented as a cartographic product at a scale of 1:100,000. We first ran an analysis within one selected buffer based on the variation in our population (no zeros in lowest quartile to increase variability) for each of the environmental factors separately. In further analyses, we tested the robustness by including the other buffers.

Distances to the nearest major road with traffic counts available and traffic density were determined using GIS functions. All GIS analyses were carried out using ArcGIS 10 software. We collected information on two traffic indicators at the children's and adolescents' residences, i.e., distance to major road and traffic density. A major road was defined a highway, national road, or large local road. ${ }^{26}$ Traffic density within a $200 \mathrm{~m}$ radius (buffer) from the residence was equal to the length of each road in this buffer multiplied with the traffic count at each specific road. This was calculated for a $200 \mathrm{~m}$ buffer in steps of $10 \mathrm{~m}$. Traffic counts of 2010 were obtained from the Traffic Centre Flanders, 
Department of Mobility and Public Works. Streets with low traffic-carrying capacity codes without traffic measurements were assigned a default traffic count of 543 vehicles per 24 hours. Traffic densities within a buffer were multiplied by a weight decreasing with distance, following a Gaussian curve. Finally the sum was made for the distance-weighted traffic densities (DWTD) in all buffers within $200 \mathrm{~m}$. This was also repeated for 50,100, 200 and $300 \mathrm{~m}$ buffers.

\subsection{Noise and air pollution exposure estimates}

For the child's residence, we used a spatial temporal interpolation method to model the daily residential exposure levels $\left(\mu \mathrm{g} / \mathrm{m}^{3}\right)$ of particulate matter $(\mathrm{PM})$ for black carbon and particles with a diameter less than or equal to $2.5 \mu \mathrm{m}\left(\mathrm{PM}_{2.5}\right)$. This method considers land-cover data obtained from satellite images of the CORINE land-cover data set and pollution data of fixed monitoring stations in combination with a dispersion model. The model calculates the daily interpolated exposure concentrations in a high resolution receptor grid based on information from the Belgian telemetric airquality networks, point sources, and line sources. Overall model performance was evaluated by leaveone-out cross-validation and was based on 34 monitoring points for $\mathrm{PM}_{2.5}$ and 14 for black carbon. Validation statistics of the interpolation tool gave a spatial temporal explained variance of more than 0.80 for $\mathrm{PM}_{2.5}$ and 0.74 for black carbon. We used the annual averages of 2015 as representative spatial contrasts.

A GIS-based noise model including the Flemish street and railway networks was used to estimate traffic noise levels in $5 \mathrm{~dB}(\mathrm{~A})$-intervals according to the European Noise Directive (2002/49/EC). ${ }^{27}$ The modeling of road noise level included road-traffic intensity, vehicle-type-specific traffic density, type of street surface, small-scale topography of the area, and the presence or dimensions of buildings and reflecting objects. Railway-noise modeling included the number of passing trains, type of trains, speed, small-scale topography of the area, and the presence or dimensions of buildings and reflecting objects. Weighted equivalent noise levels in $\mathrm{dB}(\mathrm{A})$ for traffic during the daytime (based on the weighted yearly 2011 average noise level between 7 a.m. and 7 p.m. and 7 p.m. to 11 p.m.) and at night (yearly average noise level between 11 p.m. and 7 a.m.) were modeled.

\subsection{Statistical analyses}

Statistical analyses were performed using statistical software package SAS version 9.4 (SAS Institute Inc, Cary, NC, USA), and all $p$ values $<0.05$ were considered significant. Stress parameters (sadness, anxiousness, total negative emotions, conduct problems, emotional problems, peer relationship problems, and hair cortisol) were converted to natural logarithm due to the non-normal distribution. All traffic-related parameters were also log-transformed because of skewed distributions and because traffic-related pollutants decay exponentially with increasing distance from roads. ${ }^{28} \mathrm{An}$ independent t- 
test was conducted to assess sex differences in stress and residential landscape. Correlation coefficients between residential landscape, stress, traffic, and air pollution in 2015 were estimated with Spearman correlation coefficients. Additionally, partial correlation coefficients correcting for socioeconomic status were calculated, as shown in Supplemental Table S1. Cross-sectional associations were estimated using linear regression models, with the residential landscape as the predictor and stress as the outcome. Adjustment was performed for age, sex, and socioeconomic status, and all assumptions of linear regression were met. Models with hair cortisol were in a second step additionally adjusted for date of hair cortisol analysis and hair color. Linear mixed-effect regression models were used to assess the longitudinal association between continuous residential landscape and changes in stress parameters between 2012 and 2015. Several correlation structures, including compound symmetry, unstructured, first-order autoregressive, and Toeplitz matrices were assessed for each model, and the best fitted structure was selected using Akaike's information criterion. These models were also adjusted for age, sex, and socioeconomic status. Purely for visualization of significant associations in the previously mentioned longitudinal mixed models, the residential landscape parameters were categorized into two groups ( $\geq$ median and $<$ median). The effect of noise and air pollution on the relationship between residential landscape and stress was assessed for significant cross-sectional and longitudinal associations by adding them separately into the linear regression models, and identifying changes in the relationship between residential landscape and stress. This because the effect of residential landscape on psychosocial stress might be directly or indirectly by noise and air pollution. Last, mediation models were conducted, with noise and air pollution as mediator, using the Process-macro of Hayes. ${ }^{29}$ 


\section{Results}

\subsection{Subject characteristics}

The characteristics of the study population are described in Table 1. Boys and girls differed for the SDQ subscales of emotional problems (girls more emotional problems, mean difference $0.23, p<0.01$ ) and hyperactivity problems (boys more hyperactivity problems, mean difference $0.72, p=0.01$ ) and for the emotions of anxiousness (girls experienced increased anxiousness, mean difference $0.17, p=0.01$ ), sadness (girls experienced increased sadness, mean difference $0.23, p<0.01$ ), and total negative emotions (girls reported more negative emotions, mean difference $0.20, p=0.01$ ). Table 2 describes the distribution of the residential-landscape indicators, air pollution and noise. The median land use in percentiles in a $5000 \mathrm{~m}$ buffer were $8 \%$ semi-natural and forested areas (interquartile range (IQR) = 410), $73 \%$ agricultural area (IQR $=70-77), 2 \%$ industrial area (IQR $=1-2)$, and $16 \%$ residential area (IQR $=13-17)$.

\subsection{Cross-sectional association between residential landscape and stress}

In unadjusted analyses, we found a positive correlation between a child's hyperactivity problems and residential areas within $100 \mathrm{~m}(r=0.18 ; p<0.01)$, whereas an inverse correlation was observed with agricultural areas within $300 \mathrm{~m}(\mathrm{r}=-0.19 ; p<0.01)$. Residential proximity to nature within $2000 \mathrm{~m}$ was negatively correlated with conduct problems $(r=-0.14 ; p=0.04)$ and anxiousness $(r=-0.15 ; p=0.03)$. Anger, sadness, and the sum of negative emotions correlated with industrial areas within $4000 \mathrm{~m}$ ( $\mathrm{r}=$ $0.14-0.19 ; p<0.01-0.03)$.

Aforementioned associations between residential landscape and stress (hyperactivity problems, anxiousness, sadness, sum of negative emotions) remained after adjustment for age, sex, and socioeconomic status (Table 3 and Supplemental Material Table S1). A decrease in hyperactivity problem score of -0.50 (95\% confidence interval $(\mathrm{Cl})$ : -0.93 to $-0.07, p=0.02$ ) was observed for an IQR (44\%) increase in agricultural area within $300 \mathrm{~m}$. Whereas, an inverse association was seen for an IQR (45\%) increase in residential area within $100 \mathrm{~m}$ (hyperactivity-problem score increase of $0.61,95 \% \mathrm{Cl}$ : 0.19 to $1.04, p<0.01$ ). Residential exposure to semi-natural and forested areas within $2000 \mathrm{~m}$ was positively associated with happiness: for each IQR (6\%) increase in area, there was a 0.17 increase in happiness score $(\beta=0.17, p=0.01)$. An inverse association was observed with sadness, anxiousness, and total negative emotions, wherein for each IQR higher residential density in semi-natural and forested area within $2000 \mathrm{~m}$, there was a $6.2-6.8 \%$ lower score $(\beta=-0.14$ to $-0.15, p=0.02-0.03$ ). Additional analysis with wider and smaller buffers showed similar results, as presented in the Supplemental Material Table S2. 
Higher residential traffic density was only associated with hyperactivity problems. A doubling in residential distance weighted traffic density within a $300 \mathrm{~m}$ radius was associated with an increase in hyperactivity score of $0.09(\beta=0.15, p=0.046)$. A similar trend was seen in the 50,100 , and $200 \mathrm{~m}$ buffers. We did not find any associations between hair cortisol and residential landscape.

\subsection{Longitudinal association between residential landscape and stress}

Of the 224 children, 172 were tracked over time. Significant longitudinal associations between residential landscape and change in stress score (2012-2015) were seen for industrial and semi-natural and forested areas, as shown in Figure 2. A significant time interaction coefficient was noted for industrial areas within $4000 \mathrm{~m}$ and anger $\left(p=0.028\right.$, Pseudo- $\mathrm{R}^{2}=1.83 \%$ of the variation in the angriness score change was explained by industry at baseline and follow-up). This positive coefficient indicates that industrial areas within $4000 \mathrm{~m}$ tended to increase angriness scores over time. A similar association was seen with total negative emotions as outcome $\left(p=0.013\right.$, Pseudo- $\mathrm{R}^{2}=3.80 \%$ of the variation in negative emotion score change was explained by industry at baseline and follow-up). A positive time interaction was also noted for semi-natural and forested areas within $2000 \mathrm{~m}$ and happiness $(p=0.049$, Pseudo- $R^{2}=3.31 \%$ of the variation in negative emotion score change was explained by industry at baseline and follow-up). In addition, a borderline significant negative time interaction was found for agricultural areas within $300 \mathrm{~m}$ and prosocial behavior.

\subsection{Role of noise and air pollution}

We found strong correlations between residential industrial density and $\mathrm{PM}_{2.5}(r=0.76, p<0.001)$, industrial areas and black carbon $(r=0.61, p<0.001)$ and between distance to a major road and black carbon $(r=-0.70, p<0.001)$, as shown in Supplemental Material Table S3. Whereas, only weak correlations were seen between psychosocial stress and noise and air pollution, presented in Supplemental Material Table S4. The role of noise and air pollution in the association between residential landscape and stress was assessed for the aforementioned significant cross-sectional findings. Figure 3 (and Supplemental Material Table S5) shows the robustness of our findings after multiple adjustments for noise, black carbon, and $\mathrm{PM}_{2.5}$. Considering residential exposure to black carbon, $\mathrm{PM}_{2.5}$, or noise, this did not change the cross-sectional estimates between residential landscape and psychosocial stress much. Further, aforementioned longitudinal associations did not change after adjustments for noise, black carbon, and $\mathrm{PM}_{2.5}$. In mediation models, there was a significant indirect effect of nature within $2000 \mathrm{~m}$ on sadness through noise pollution (indirect effect $b$ $=-0.002$; bootstrapCl -0.005 ; to -0.001 ), and a significant effect of nature within $2000 \mathrm{~m}$ on negative emotions through noise pollution (indirect effect $b=-0.002$; bootstrapCl -0.005 to -0.004 ). The ratio of indirect effect to the total effect was 0.18 and 0.16 respectively. 


\section{Discussion}

This longitudinal study in a semi-urban densely populated area provides new insights into the association between residential landscape and psychosocial stress in children and adolescents. In cross-sectional analyses, an increase in greenness, e.g., semi-natural and forested areas and agricultural areas, was associated with increased feelings of happiness and decreased feelings of sadness, anxiousness, total negative emotions, and hyperactivity problems. An opposite relationship was seen with hyperactivity problems for residential areas and traffic density. In the longitudinal analysis, tracking a three-year time period between childhood and adolescence, residential industrial areas were associated with increased feelings of anger and total negative emotions. Consequently, higher residential exposure to semi-natural and forested areas were associated with increased feelings of happiness. Our results could not be explained by socioeconomic factors, residential noise, or air pollution exposure, suggesting an independent association of residential greenness. Based on both cross-sectional and longitudinal analysis, we suggest that greenness close to a home might have a beneficial effect on stress levels in children and adolescents, while residential and industrial areas and residential traffic have an unfavorable effect.

\subsection{Greenness}

Greenness (semi-natural and forested areas and agricultural areas) might have a beneficial effect on stress levels in children and adolescents. Both cross-sectional and longitudinal analyses showed that a higher percentage of semi-natural and forested areas was associated with better emotional status. Concerning behavioral problems, only one aspect of the SDQ was associated with greenness, namely, hyperactivity problems.

Studies in adults have shown similar results, where increased areas with green space reduced stress. ${ }^{13-}$ 15,17,30 Emotional childhood status has not been investigated in relation to greenness; however, studies have found similar negative associations with the SDQ subscale hyperactivity problems. ${ }^{31,32}$ Other childhood studies have additionally found negative associations with the SDQ subscales of peer problems, conduct problems, and the total difficulties score. ${ }^{31-34}$ Besides the proximity of greenness, it might also be the use of the green space that has an effect on stress reduction. A study in Barcelona schoolchildren noted associations with green-space playing time and lower SDQ total difficulties scores, emotional problems, and peer relationship problems. ${ }^{33}$

The possible mechanism explaining the relationship between greenness and reduced stress level is not fully understood. However, it has been hypothesized that the beneficial effects of green spaces are through the reduction of air pollution and an increasement in the amount the time people spend 
outdoors and are physically active. ${ }^{35}$ However, our results on residential landscape were not fully explained by residential noise and air pollution. Another theory suggested that greenness could provide a buffer against the negative health impact of stressful life events. ${ }^{36}$ Van den Berg et al. showed that participants with a large amount of green space in a $3 \mathrm{~km}$ radius were less affected when experiencing a stressful life event than respondents with a small amount of green space in that radius. ${ }^{36}$ In addition, experiments have shown that viewing slides or videos of natural environments leads to a faster and more complete stress recovery. ${ }^{37,38}$ This might be explained by the stress recovery theory of Ulrich et al. ${ }^{10}$, which focuses on the evolutionary aspects of human evolvement over a long period in natural environments, which might have made them better adapted to a more natural environment, as opposed to an urban environment.

\subsection{Industrial and residential areas and traffic}

In accordance with the beneficial effects of greenness, our results on industrial areas and residential traffic exposure showed detrimental associations (more negative emotions and hyperactivity problems). These results might suggest that a lack of open space and increased traffic-related air pollution negatively impact children's and adolescents' stress levels, potentially by activation of the hypothalamic-pituitary-adrenal axis due to air pollution, which increases cortisol levels. ${ }^{39,40}$ Higher perceived stress in adults is indeed associated with increased air pollution. ${ }^{30} \mathrm{However}$, in this childhood study, the role of noise and air pollution was rather small. Further, noise and air pollution were clearly associated with residential landscape, but there was only a weak correlation between noise and/or air pollution and stress parameters. Mediation models showed that a relatively small part of the association between nature within $2000 \mathrm{~m}$ and negative emotions, i.e. sadness and total negative emotions, was due to an indirect effect of noise, not air pollution. Nor was there mediation by noise and air pollution for the other associations. A part of the association between residential landscape and stress might thus be explained by noise, however this is relatively small. It might thus be that this relation is mostly due to the direct effects of greenness, by creating visual/psychological stimulations and activities outdoors, as mentioned before.

\subsection{Clinical importance}

This study might indicate an association between the residential landscape and psychosocial stress. On average, a ten percent change in stress score was seen per IQR increase of land use. The effect of land use on stress might thus be more important from a preventive point of view, rather than a clinical point of view. As mentioned before, chronic stress could eventually lead to multiple diseases due to a potential overload of the immune, nervous, and endocrine systems. ${ }^{11,12}$ Obesity, metabolic syndrome, cardiovascular problems, and depression have all been linked to stress. ${ }^{41-44}$ In addition, chronic 
childhood stress might even have harmful effects on health in adulthood. ${ }^{12}$ This detrimental pathway might be facilitated by telomeres, e.g., the end caps of chromosomes, which could shorten (a sign of accelerated aging) due to stress. ${ }^{45}$ Our data might also suggest a specific vulnerable period to residential-landscape factors between childhood and adolescence since associations of industry with emotional status only appeared in the longitudinal analyses.

\subsection{Strength and limitations}

To our knowledge, this is one of the first longitudinal studies assessing the direct association between residential landscape and psychosocial stress from childhood to adolescence. Major assets are the longitudinal stress data over three years, the use of both subjective and objective stress measurements, and the inclusion of noise and air pollution in the association between the residential landscape and stress.

Some limitations of the study still need to be addressed. First, the longitudinal analysis included only a relatively small population of children who did not move between 2012 and 2015 . Unfortunately, we have no knowledge on how long these children already lived at this residence (and thus were exposed to the landscape). Second, we only investigated the residential landscape in a $100 \mathrm{~m}$ to $5 \mathrm{~km}$ radius from the participants' homes, although children spend a considerable portion of their time at school. Consequently, effects of residential landscape might be underestimated in the current manuscript and might become clearer when considering also the school's residential landscape. Third, all participants were from the community of Aalter, a small city surrounded by agriculture and near a highway. It also remains to be tested whether the results of this study are also applicable to children living in larger cities or in the countryside without major motorways. Fourth, socioeconomic status was only assessed using highest achieved parental education; no financial information was available. Fifth, in this study, we were not able to detect any relationship with the objective stress biomarker hair cortisol. This may be due to the collection method, as hair cortisol levels provide an average stress level during the last three months without detecting fluctuating daily changes, or due to potential selection bias in hair cortisol samples, as hair cortisol was measured more in girls as compared to boys, due to the length of hair needed for analysis. Sixth, there was a slight difference in detected significant associations when comparing the SDQ subscale emotional problems and the emotion questionnaire with greenness in our study. This might be because of a different focus (SDQ is more behavioral focused) or a potential bias by the person filling in the questionnaires (SDQ was filled in by the parents, while the emotion questionnaire was filled in by the children). Seventh, we tried to increase variability and unity in the buffer selection of the residential-landscape predictors by selecting the buffer with no zeros in the lowest quartile. However, variability might still be small; therefore, we additionally performed the analysis with the other buffers as predictors, as shown in Supplemental Material Table S2. Here, similar 
results were obtained as with the buffers mentioned in the manuscript results section. Eighth, distance to major roads was used as a crude measure; however, proxies of exposure, such as residential proximity to major roads, have recently been shown to be associated with internal exposure to nanosized particles, reflecting exposure to black carbon. ${ }^{46}$ Finally, our noise and air pollution data were based on high-resolution models, which combine measures with land use data, resulting in some interrelations.

\subsection{Conclusion}

Greenness in proximity to a home, e.g., semi-natural and forested areas and agricultural areas, was associated with a better childhood emotional status (increased feelings of happiness and decreased feelings of sadness, anxiousness, and total negative emotions). Whereas, an opposite relationship was seen with hyperactivity problems for residential areas and traffic density. Longitudinal analysis of children tracked over a three-year time period between childhood and adolescence showed that residential industrial areas were associated with increased feelings of anger and total negative emotions. When designing or renovating residential areas, urban designers and local, regional, and national policies might consider integrating adequate levels of green environment to prevent the potential detrimental health effects of stress in both children and teenagers.

\section{Acknowledgments}

The authors would like to thank all the children and parents for their voluntary participation in this study. This work was supported by the Research Foundation - Flanders, Belgium (project number G073315N), and the geographical information system was supported by the EU Program "Ideas" (ERC2012-StG 310898). Bram Janssen is a postdoctoral fellow of the Research Foundation - Flanders, Belgium (FWO). 


\section{References}

1. Lachowycz K, Jones AP. Greenspace and obesity: a systematic review of the evidence. Obes Rev 2011;12:e183-e9.

2. James P, Banay RF, Hart JE, Laden F. A Review of the Health Benefits of Greenness. Curr Epidemiol Rep 2015;2:131-42.

3. Bodicoat DH, O'Donovan G, Dalton AM, et al. The association between neighbourhood greenspace and type 2 diabetes in a large cross-sectional study. Bmj Open 2014;4.

4. Maas J, Verheij RA, de Vries S, Spreeuwenberg P, Schellevis FG, Groenewegen PP. Morbidity is related to a green living environment. J Epidemiol Commun H 2009;63:967-73.

5. McEachan RRC, Prady SL, Smith G, et al. The association between green space and depressive symptoms in pregnant women: moderating roles of socioeconomic status and physical activity. J Epidemiol Commun H 2016;70:253-9.

6. Beyer KMM, Kaltenbach A, Szabo A, Bogar S, Nieto FJ, Malecki KM. Exposure to Neighborhood Green Space and Mental Health: Evidence from the Survey of the Health of Wisconsin. Int J Env Res Pub He 2014;11:3453-72.

7. Orban E, McDonald K, Sutcliffe R, et al. Residential Road Traffic Noise and High Depressive Symptoms after Five Years of Follow-up: Results from the Heinz Nixdorf Recall Study. Environ Health Persp 2016;124:578-85.

8. Marques S, Lima ML. Living in grey areas: Industrial activity and psychological health. J Environ Psychol 2011;31:314-22.

9. Wilson EO. Biophilia: Cambridge (Mass.) : Harvard university press; 1984.

10. Ulrich RS, Simons RF, Losito BD, Fiorito E, Miles MA, Zelson M. Stress Recovery during Exposure to Natural and Urban Environments. J Environ Psychol 1991;11:201-30.

11. McEwen BS. Physiology and neurobiology of stress and adaptation: Central role of the brain. Physiol Rev 2007;87:873-904.

12. Danese A, McEwen BS. Adverse childhood experiences, allostasis, allostatic load, and agerelated disease. Physiol Behav 2012;106:29-39.

13. Roe JJ, Thompson CW, Aspinall PA, et al. Green Space and Stress: Evidence from Cortisol Measures in Deprived Urban Communities. Int J Env Res Pub He 2013;10:4086-103.

14. Thompson CW, Roe J, Aspinall P, Mitchell R, Clow A, Miller D. More green space is linked to less stress in deprived communities: Evidence from salivary cortisol patterns. Landscape Urban Plan 2012;105:221-9.

15. Nielsen TS, Hansen KB. Do green areas affect health? Results from a Danish survey on the use of green areas and health indicators. Health Place 2007;13:839-50.

16. Lee ACK, Maheswaran R. The health benefits of urban green spaces: a review of the evidence. J Public Health-Uk 2011;33:212-22.

17. Grahn P, Stigsdotter UA. Landscape planning and stress. Urban for Urban Gree 2003;2:1-18.

18. Ahrens W, Bammann K, Siani A, et al. The IDEFICS cohort: design, characteristics and participation in the baseline survey. Int J Obesity 2011;35:S3-S15.

19. Michels N, Vanaelst B, Vyncke K, et al. Children's Body composition and Stress - the ChiBS study: aims, design, methods, population and participation characteristics. Arch Public Health 2012;70:17.

20. International Standard Classification of Education. 2010. at http://uis.unesco.org/.)

21. Municipality characteristics (Uw gemeente in cijfers). 2011. (Accessed 26 September 2017, at http://statbel.fgov.be/nl/statistieken/chiffcomm/.)

22. McCance K, Forshee, B., Shelby J. Stress and disease. Pathophysiology: The biologic basis for disease in adults and children. 5 ed. St Louis: Mosby2006.

23. Goodman R. The Strengths and Difficulties Questionnaire: a research note. J Child Psychol Psychiatry 1997;38:581-6. 
24. Wester VL, van Rossum EF. Clinical applications of cortisol measurements in hair. Eur J Endocrinol 2015;173:M1-10.

25. Michels N, Van de Wiele T, De Henauw S. Chronic Psychosocial Stress and Gut Health in Children: Associations With Calprotectin and Fecal Short-Chain Fatty Acids. Psychosom Med 2016.

26. Nawrot TS, Vos R, Jacobs $L$, et al. The impact of traffic air pollution on bronchiolitis obliterans syndrome and mortality after lung transplantation. Thorax 2011;66:748-54.

27. Directive 2002/49/ec of the european parliament and of the council of 25 june 2002 relating to the assessment and management of environmental noise. 2002. (Accessed 01-07-2016, at http://eur-lex.europa.eu/legal-content/EN/TXT/PDF/?uri=CELEX:32002L0049\&from=EN.)

28. Zhu Y, Hinds WC, Kim S, Sioutas C. Concentration and size distribution of ultrafine particles near a major highway. J Air Waste Manag Assoc 2002;52:1032-42.

29. Hayes AF. Introduction to Mediation, Moderation, and Conditional Process Analysis. 2 ed. New York: Guilford press; 2018.

30. Mehta AJ, Kubzansky LD, Coull BA, et al. Associations between air pollution and perceived stress: the Veterans Administration Normative Aging Study. Environ Health-Glob 2015;14.

31. Markevych I, Tiesler CMT, Fuertes E, et al. Access to urban green spaces and behavioural problems in children: Results from the GINIplus and LISAplus studies. Environ Int 2014;71:29-35.

32. Balseviciene B, Sinkariova L, Grazuleviciene R, et al. Impact of Residential Greenness on Preschool Children's Emotional and Behavioral Problems. Int J Env Res Pub He 2014;11:6757-70.

33. Amoly E, Dadvand P, Forns J, et al. Green and Blue Spaces and Behavioral Development in Barcelona Schoolchildren: The BREATHE Project. Environ Health Persp 2014;122:1351-8.

34. Flouri E, Midouhas E, Joshi H. The role of urban neighbourhood green space in children's emotional and behavioural resilience. J Environ Psychol 2014;40:179-86.

35. Tzoulas K, Korpela K, Venn S, et al. Promoting ecosystem and human health in urban areas using Green Infrastructure: A literature review. Landscape Urban Plan 2007;81:167-78.

36. van den Berg AE, Maas J, Verheij RA, Groenewegen PP. Green space as a buffer between stressful life events and health. Soc Sci Med 2010;70:1203-10.

37. Berto $R$. The role of nature in coping with psycho-physiological stress: a literature review on restorativeness. Behav Sci (Basel) 2014;4:394-409.

38. van den Berg AE, Koole SL, van der Wulp NY. Environmental preference and restoration: (How) are they related? J Environ Psychol 2003;23:135-46.

39. Millers DB, Ghio AJ, Karoly ED, et al. Ozone Exposure Increases Circulating Stress Hormones and Lipid Metabolites in Humans. Am J Resp Crit Care 2016;193:1382-91.

40. Thomson EM. Neurobehavioral and metabolic impacts of inhaled pollutants. Endocrine Disruptors 2013;1:e27489.

41. Dallman MF, Pecoraro N, Akana SF, et al. Chronic stress and obesity: a new view of "comfort food". Proc Natl Acad Sci U S A 2003;100:11696-701.

42. Chandola T, Brunner E, Marmot M. Chronic stress at work and the metabolic syndrome: prospective study. Brit Med J 2006;332:521-4a.

43. Dimsdale JE. Psychological stress and cardiovascular disease. J Am Coll Cardiol 2008;51:1237-

46.

44. Hammen C. Stress and depression. Annu Rev Clin Psycho 2005;1:293-319.

45. Mathur MB, Epel E, Kind S, et al. Perceived stress and telomere length: A systematic review, meta-analysis, and methodologic considerations for advancing the field. Brain Behav Immun 2016;54:158-69.

46. Saenen ND, Bove H, Steuwe C, et al. Children's Urinary Environmental Carbon Load. A Novel Marker Reflecting Residential Ambient Air Pollution Exposure? Am J Respir Crit Care Med 2017;196:873-81. 


\section{Tables}

Table 1. Characteristics of the study population.

\begin{tabular}{|c|c|c|}
\hline & \multicolumn{2}{|c|}{ Study wave } \\
\hline & $\begin{array}{c}2012 \\
(N=172)\end{array}$ & $\begin{array}{c}2015 \\
(N=224)\end{array}$ \\
\hline Age (year) & $9.7(8.7-10.7)$ & $12.5(11.1-13.7)$ \\
\hline Males (\%) & $89(50.9)$ & $113(50.4)$ \\
\hline High socioeconomic status (\%) & $124(72.1)$ & $160(71.4)$ \\
\hline \multicolumn{3}{|l|}{ Emotion scores } \\
\hline Happy (0-10) & $8(7-9)$ & $8(7-9)$ \\
\hline Sad (0-10) & $1(0-4)$ & $1(0-3)$ \\
\hline Anxious (0-10) & $0(0-2)$ & $0(0-2)$ \\
\hline Angry (0-10) & $2(1-3)$ & $2(1-3)$ \\
\hline Negative emotions $(0-30)^{a}$ & $5(2-8)$ & $4(2-7)$ \\
\hline \multicolumn{3}{|l|}{ SDQ } \\
\hline Conduct problems (0-10) & $1(0-2)$ & $1(0-2)$ \\
\hline Hyperactivity problems (0-10) & $3(1-4)$ & $3(1-5)$ \\
\hline Emotional problems (0-10) & $2(1-4)$ & $2(1-4)$ \\
\hline Peer problems $(0-10)$ & $1(0-2)$ & $1(0-2)$ \\
\hline Prosocial behavior (0-10) & $9(8-10)$ & $9(8-10)$ \\
\hline Total difficulties score $(0-40)^{b}$ & $7(5-11)$ & $8(5-11)$ \\
\hline Hair cortisol $(\mathrm{pg} / \mathrm{mg})^{\mathrm{c}}$ & & $1.6(1.3-1.8)$ \\
\hline \multicolumn{3}{|c|}{ Abbreviation: SDQ, Strength and Difficulties Questionnaire. Values are expressed as } \\
\hline \multicolumn{3}{|c|}{ a Sum of sadness, anxiousness and anger } \\
\hline \multicolumn{3}{|c|}{${ }^{\mathrm{b}}$ Sum of conduct, hyperactivity, emotional, and peer problems } \\
\hline${ }^{c} N=153$ & & \\
\hline
\end{tabular}


Table 2. Distribution of the land use, traffic, and air pollution indicators.

\begin{tabular}{|c|c|c|c|c|c|}
\hline & $5^{\text {th }}$ & $25^{\text {th }}$ & $50^{\text {th }}$ & $75^{\text {th }}$ & $95^{\text {th }}$ \\
\hline \multicolumn{6}{|l|}{ Land-use indicators $^{a}$} \\
\hline $\begin{array}{l}\text { Semi-natural and forested area: } 2000 \text { m } \\
\text { buffer, \% }\end{array}$ & 0 & 1 & 2 & 7 & 29 \\
\hline Agricultural area: 300 m buffer, \% & 0 & 13 & 34 & 57 & 99 \\
\hline Industrial area: 4000 m buffer, \% & 0 & 1 & 2 & 3 & 3 \\
\hline Residential area: 100 m buffer, \% & 0 & 44 & 94 & 99 & 99 \\
\hline \multicolumn{6}{|l|}{ Traffic indicators } \\
\hline Distance to major road, $\mathrm{m}$ & 62 & 193 & 437 & 1033 & 2184 \\
\hline $\begin{array}{l}\text { Distance weighted traffic density in a } 50 \\
\text { m buffer, vehicles * km/day }\end{array}$ & 0 & 24536 & 33451 & 45412 & 73489 \\
\hline $\begin{array}{l}\text { Distance weighted traffic density in a } \\
100 \mathrm{~m} \text { buffer, vehicles * km/day }\end{array}$ & 35854 & 59105 & 83233 & 109662 & 536200 \\
\hline \multicolumn{6}{|l|}{$200 \mathrm{~m}$ buffer, vehicles $*$ km/day } \\
\hline \multicolumn{5}{|l|}{$300 \mathrm{~m}$ buffer, vehicles $* \mathrm{~km} / \mathrm{day}$} & 931401 \\
\hline \multicolumn{6}{|l|}{ Noise and air pollution indicators } \\
\hline Noise, day and night, $d B$ & 45 & 45 & 45 & 57 & 62 \\
\hline 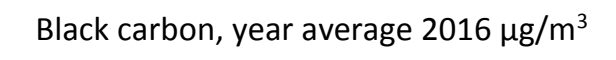 & 0.81 & 0.89 & 0.92 & 0.99 & 1.09 \\
\hline $\mathrm{PM}_{2.5}$, year average $2016 \mu \mathrm{g} / \mathrm{m}^{3}$ & 11.7 & 12.1 & 12.3 & 12.8 & 13.2 \\
\hline $\begin{array}{l}\text { Abbreviation: PM, particulate matter } \\
\text { a Buffers were chosen for each land-use ind } \\
\text { increase variability) }\end{array}$ & ator sep & ately (no & eros in lo & est quart & e to \\
\hline
\end{tabular}


Table 3. Cross-sectional associations between residential landscape (land use and traffic) and stress-related parameters (behavior, emotions, and hair cortisol) in 2015.

\begin{tabular}{|c|c|c|c|c|c|c|c|c|c|c|c|c|}
\hline & \multicolumn{12}{|c|}{ Behavior } \\
\hline & \multicolumn{2}{|c|}{ Conduct problems } & \multicolumn{2}{|c|}{$\begin{array}{l}\text { Hyperactivity } \\
\text { problems }\end{array}$} & \multicolumn{2}{|c|}{$\begin{array}{l}\text { Emotional } \\
\text { problems }\end{array}$} & \multicolumn{2}{|c|}{ Peer problems } & \multicolumn{2}{|c|}{ Prosocial behavior } & \multicolumn{2}{|c|}{$\begin{array}{l}\text { Total difficulties } \\
\text { score }\end{array}$} \\
\hline & $\beta$ & $95 \% \mathrm{Cl}$ & $\beta$ & $95 \% \mathrm{Cl}$ & $\beta$ & $95 \% \mathrm{Cl}$ & $\beta$ & $95 \% \mathrm{Cl}$ & $\beta$ & $95 \% \mathrm{Cl}$ & $\beta$ & $95 \% \mathrm{Cl}$ \\
\hline \multicolumn{13}{|l|}{ Land-use indicators $^{\mathrm{a}}$} \\
\hline $\begin{array}{l}\text { Semi-natural and forested area, } \\
2000 \mathrm{~m} \text { buffer }\end{array}$ & -0.092 & $\begin{array}{l}-0.225 \\
0.040\end{array}$ & 0.029 & $\begin{array}{l}-0.102 \\
0.160\end{array}$ & -0.065 & $\begin{array}{l}-0.192 \\
0.064\end{array}$ & -0.130 & $\begin{array}{l}-0.263 \\
0.001\end{array}$ & -0.007 & $\begin{array}{l}-0.140 \\
0.127\end{array}$ & -0.069 & $\begin{array}{l}-0.199 \\
0.062\end{array}$ \\
\hline Agricultural area, $300 \mathrm{~m}$ buffer & -0.101 & $\begin{array}{l}-0.258 \\
0.003\end{array}$ & $-0.151 *$ & $\begin{array}{l}-0.308 \\
-0.053\end{array}$ & 0.051 & $\begin{array}{l}-0.096 \\
0.157\end{array}$ & 0.033 & $\begin{array}{l}-0.094 \\
0.168\end{array}$ & 0.040 & $\begin{array}{l}-0.081 \\
0.182\end{array}$ & -0.039 & $\begin{array}{l}-0.193 ; \\
0.064\end{array}$ \\
\hline Industrial area, $4000 \mathrm{~m}$ buffer & 0.111 & $\begin{array}{l}-0.023 ; \\
0242\end{array}$ & 0.117 & $\begin{array}{l}-0.015 \\
0.246\end{array}$ & 0.011 & $\begin{array}{l}-0.118 \\
0.138\end{array}$ & 0.012 & $\begin{array}{l}-0.121 \\
0.144\end{array}$ & -0.084 & $\begin{array}{l}-0.216 \\
0.050\end{array}$ & 0.084 & $\begin{array}{l}-0.048 \\
0.212\end{array}$ \\
\hline Residential area, $100 \mathrm{~m}$ buffer & 0.128 & $\begin{array}{l}-0.004 \\
0.262\end{array}$ & $0.147^{*}$ & $\begin{array}{l}0.018 \\
0.279\end{array}$ & 0.041 & $\begin{array}{l}-0.088 \\
0.170\end{array}$ & -0.023 & $\begin{array}{l}-0.157 \\
0.111\end{array}$ & -0.021 & $\begin{array}{l}-0.155 \\
0.113\end{array}$ & 0.091 & $\begin{array}{c}-0.040 \\
0.222\end{array}$ \\
\hline \multicolumn{13}{|l|}{ Traffic indicators } \\
\hline Distance to major road (m) & -0.035 & $\begin{array}{c}-0.167 \\
0.098\end{array}$ & 0.012 & $\begin{array}{l}-0.119 \\
0.143\end{array}$ & 0.018 & $\begin{array}{l}-0.110 \\
0.145\end{array}$ & -0.010 & $\begin{array}{l}-0.143 \\
0.122\end{array}$ & 0.030 & $\begin{array}{l}-0.103 \\
0.162\end{array}$ & -0.002 & $\begin{array}{l}-0.132 \\
0.128\end{array}$ \\
\hline $\begin{array}{l}\text { Distance weighted traffic density } \\
\text { in a } 50 \mathrm{~m} \text { buffer }\end{array}$ & 0.068 & $\begin{array}{l}-0.069 \\
0.219\end{array}$ & $0.181^{* *}$ & $\begin{array}{l}0.056 \\
0.336\end{array}$ & -0.069 & $\begin{array}{l}-0.214 \\
0.063\end{array}$ & -0.028 & $\begin{array}{l}-0.176 \\
0.112\end{array}$ & -0.024 & $\begin{array}{l}-0.171 \\
0.119\end{array}$ & 0.055 & $\begin{array}{l}-0.085 \\
0.199\end{array}$ \\
\hline $\begin{array}{l}\text { Distance weighted traffic density } \\
\text { in a } 100 \mathrm{~m} \text { buffer }\end{array}$ & 0.003 & $\begin{array}{l}-0.154 \\
0.149\end{array}$ & $0.145^{*}$ & $\begin{array}{l}0.017 \\
0.313\end{array}$ & -0.033 & $\begin{array}{l}-0.189 \\
0.104\end{array}$ & 0.002 & $\begin{array}{l}-0.157 \\
0.146\end{array}$ & 0.007 & $\begin{array}{l}-0.148 \\
0.156\end{array}$ & 0.058 & $\begin{array}{l}-0.087 \\
0.210\end{array}$ \\
\hline $\begin{array}{l}\text { Distance weighted traffic density } \\
\text { in a } 200 \mathrm{~m} \text { buffer }\end{array}$ & 0.054 & $\begin{array}{c}-0.079 \\
0.186\end{array}$ & $0.131^{*}$ & $\begin{array}{l}0.002 \\
0.262\end{array}$ & 0.023 & $\begin{array}{l}-0.105 \\
0.151\end{array}$ & 0.023 & $\begin{array}{l}-0.109 \\
0.156\end{array}$ & 0.002 & $\begin{array}{l}-0.131 \\
0.135\end{array}$ & 0.071 & $\begin{array}{l}-0.060 \\
0.200\end{array}$ \\
\hline \multirow[t]{4}{*}{$\begin{array}{l}\text { Distance weighted traffic density } \\
\text { in a } 300 \mathrm{~m} \text { buffer }\end{array}$} & 0.059 & $\begin{array}{c}-0.074 \\
0.191\end{array}$ & $0.132 *$ & $\begin{array}{l}0.002 \\
0.263\end{array}$ & 0.026 & $\begin{array}{l}-0.103 \\
0.154\end{array}$ & 0.026 & $\begin{array}{c}-0.107 \\
0.159\end{array}$ & 0.000 & $\begin{array}{l}-0.133 \\
0.134\end{array}$ & 0.074 & $\begin{array}{l}-0.057 \\
0.203\end{array}$ \\
\hline & \multicolumn{8}{|c|}{ Emotions } & & & \multicolumn{2}{|c|}{ Cortisol } \\
\hline & \multicolumn{2}{|c|}{ Happy } & \multicolumn{2}{|c|}{ Sad } & \multicolumn{2}{|c|}{ Anxious } & \multicolumn{2}{|c|}{ Angry } & \multicolumn{2}{|c|}{$\begin{array}{l}\text { Total negative } \\
\text { emotions }\end{array}$} & \multicolumn{2}{|c|}{ Hair cortisol } \\
\hline & $\beta$ & $95 \% \mathrm{Cl}$ & $\beta$ & $95 \% \mathrm{Cl}$ & $\beta$ & $95 \% \mathrm{Cl}$ & $\beta$ & $95 \% \mathrm{Cl}$ & $\beta$ & $95 \% \mathrm{Cl}$ & $\beta$ & $95 \% \mathrm{Cl}$ \\
\hline
\end{tabular}




\begin{tabular}{|c|c|c|c|c|c|c|c|c|c|c|c|c|}
\hline \multicolumn{13}{|l|}{ Land-use indicators $^{\mathrm{a}}$} \\
\hline $\begin{array}{l}\text { Semi-natural and forested area, } \\
2000 \text { m buffer }\end{array}$ & $0.167^{*}$ & $\begin{array}{l}0.036 \\
0.303\end{array}$ & $-0.157^{*}$ & $\begin{array}{l}-0.290 \\
-0.031\end{array}$ & $-0.140 *$ & $\begin{array}{l}-0.269 \\
-0.010\end{array}$ & -0.044 & $\begin{array}{l}-0.177 \\
0.086\end{array}$ & $-0.152 *$ & $\begin{array}{l}-0.285 \\
-0.027\end{array}$ & 0.019 & $\begin{array}{l}-0.224 \\
0.099\end{array}$ \\
\hline Agricultural area, $300 \mathrm{~m}$ buffer & 0.035 & $\begin{array}{l}-0.097 \\
0.169\end{array}$ & -0.044 & $\begin{array}{l}-0.174 \\
0.084\end{array}$ & 0.056 & $\begin{array}{l}-0.072 \\
0.182\end{array}$ & 0.014 & $\begin{array}{l}-0.115 \\
0.144\end{array}$ & 0.017 & $\begin{array}{l}-0.112 \\
0.145\end{array}$ & -0.046 & $\begin{array}{l}-0.275 \\
0.027\end{array}$ \\
\hline Industrial area, $4000 \mathrm{~m}$ buffer & -0.048 & $\begin{array}{l}-0.180 \\
0.085\end{array}$ & 0.119 & $\begin{array}{l}-0.010 \\
0.246\end{array}$ & 0.007 & $\begin{array}{l}-0.121 \\
0.135\end{array}$ & 0.093 & $\begin{array}{l}-0.035 \\
0.221\end{array}$ & 0.113 & $\begin{array}{l}-0.015 \\
0.240\end{array}$ & 0.106 & $\begin{array}{l}-0.040 \\
0.295\end{array}$ \\
\hline Residential area, $100 \mathrm{~m}$ buffer & -0.020 & $\begin{array}{l}-0.155 \\
0.115\end{array}$ & 0.031 & $\begin{array}{l}-0.099 \\
0.163\end{array}$ & -0.049 & $\begin{array}{l}-0.178 \\
0.081\end{array}$ & -0.024 & $\begin{array}{l}-0.156 \\
0.107\end{array}$ & -0.023 & $\begin{array}{l}-0.154 \\
0.108\end{array}$ & 0.105 & $\begin{array}{l}-0.005 ; \\
0.312\end{array}$ \\
\hline \multicolumn{13}{|l|}{ Traffic indicators } \\
\hline Distance to major road (m) & 0.008 & $\begin{array}{l}-0.125 \\
0.139\end{array}$ & -0.014 & $\begin{array}{l}-0.142 \\
0.114\end{array}$ & 0.029 & $\begin{array}{l}-0.098 \\
0.155\end{array}$ & 0.038 & $\begin{array}{l}-0.089 \\
0.167\end{array}$ & 0.011 & $\begin{array}{l}-0.116 \\
0.139\end{array}$ & 0.026 & $\begin{array}{c}-0.211 ; \\
0.096\end{array}$ \\
\hline $\begin{array}{l}\text { Distance weighted traffic density } \\
\text { in a } 50 \mathrm{~m} \text { buffer }\end{array}$ & 0.005 & $\begin{array}{l}-0.136 \\
0.141\end{array}$ & 0.021 & $\begin{array}{l}-0.113 \\
0.159\end{array}$ & 0.030 & $\begin{array}{l}-0.101 \\
0.170\end{array}$ & -0.051 & $\begin{array}{l}-0.184 \\
0.084\end{array}$ & -0.038 & $\begin{array}{l}-0.175 \\
0.097\end{array}$ & 0.069 & $\begin{array}{c}-0.115 ; \\
0.203\end{array}$ \\
\hline $\begin{array}{l}\text { Distance weighted traffic density } \\
\text { in a } 100 \mathrm{~m} \text { buffer }\end{array}$ & 0.004 & $\begin{array}{l}-0.143 \\
0.158\end{array}$ & 0.070 & $\begin{array}{l}-0.069 \\
0.222\end{array}$ & 0.031 & $\begin{array}{l}-0.104 \\
0.184\end{array}$ & -0.065 & $\begin{array}{l}-0.217 \\
0.074\end{array}$ & -0.022 & $\begin{array}{l}-0.170 \\
0.120\end{array}$ & 0.061 & $\begin{array}{c}-0.078 \\
0.234\end{array}$ \\
\hline $\begin{array}{l}\text { Distance weighted traffic density } \\
\text { in a } 200 \mathrm{~m} \text { buffer }\end{array}$ & 0.028 & $\begin{array}{l}-0.104 \\
0.158\end{array}$ & 0.076 & $\begin{array}{l}-0.052 \\
0.201\end{array}$ & -0.003 & $\begin{array}{l}-0.129 \\
0.123\end{array}$ & -0.046 & $\begin{array}{l}-0.173 \\
0.081\end{array}$ & -0.004 & $\begin{array}{l}-0.130 \\
0.123\end{array}$ & 0.052 & $\begin{array}{c}-0.070 \\
0.216\end{array}$ \\
\hline $\begin{array}{l}\text { Distance weighted traffic density } \\
\text { in a } 300 \mathrm{~m} \text { buffer }\end{array}$ & 0.026 & $\begin{array}{l}-0.105 \\
0.157\end{array}$ & 0.077 & $\begin{array}{l}-0.051 \\
0.203\end{array}$ & -0.005 & $\begin{array}{l}-0.131 \\
0.122\end{array}$ & -0.049 & $\begin{array}{l}-0.176 \\
0.079\end{array}$ & -0.004 & $\begin{array}{l}-0.131 \\
0.123\end{array}$ & 0.047 & $\begin{array}{l}-0.071 ; \\
0.216\end{array}$ \\
\hline \multicolumn{13}{|c|}{$\begin{array}{l}\text { Linear regression models adjusted for age, sex and parental socioeconomic status. } \\
*<0.05 * *<0.01 \text {. }\end{array}$} \\
\hline
\end{tabular}




\section{Figure legends}

1

2 Figure 1. Flow chart of inclusion and exclusion of study participants.

3

4 Figure 2. Land use as a predictor of change in emotional stress scores between 2012 and 2015. A, 5 industrial area as a predictor of anger; B, industrial area as a predictor of the total negative emotions;

6 C, semi-natural and forested area as a predictor of happiness. Estimated means for emotional stress

7 are adjusted for age, sex, and socioeconomic status, with continuous predictor and outcome variables.

8 Purely for visualization of significant associations in the longitudinal mixed models, the residential landscape parameters were categorized into two groups ( $\geq$ median and $<$ median). The solid line 11 indicates participants with land use above median, and the dashed line indicates those below median.

Figure 3. Models assessing the role of noise and air pollution on the cross-sectional relationship between residential landscape and stress-related parameters. The basic linear regression model is adjusted for age, sex, and socioeconomic status; the other models are additionally adjusted for noise, black carbon, or particulate matter (PM2.5). 
Figure 1. Flow chart of inclusion and exclusion of study participants.

18

19

20

21

22

23

24

25

26

27

28

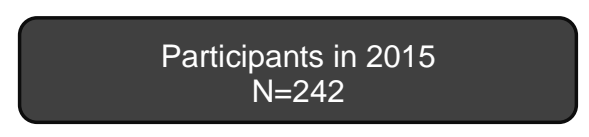

Participants with stress,

environmental and socioeconomic

status data in 2015

$\mathrm{N}=224$

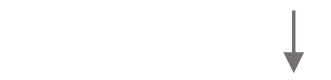

Participants who did not move between 2012 and 2015

$\mathrm{N}=193$

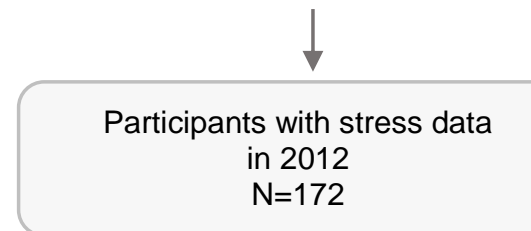

\section{Cross-sectional}

Longitudinal 
Figure 2. Land use as a predictor of change in emotional stress score between 2012 and 2015 . A, industrial area as a predictor of anger; B, industrial area as a predictor of

socioeconomic status, with continuous predictor and outcome variables. Purely for visualization of significant associations in the longitudinal mixed models, the residential landscape parameters were categorized into two groups ( $\geq$ median and $<$ median). The solid line indicates participants with land use above median, and the dashed line

A

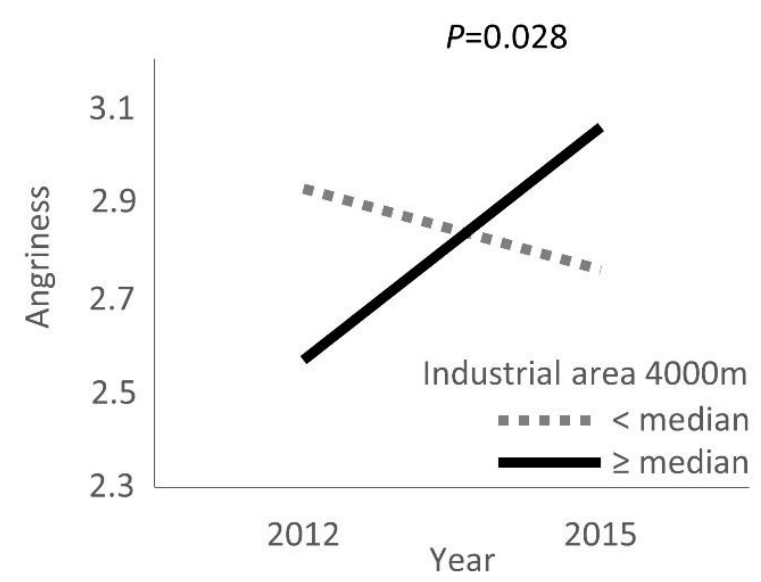

B

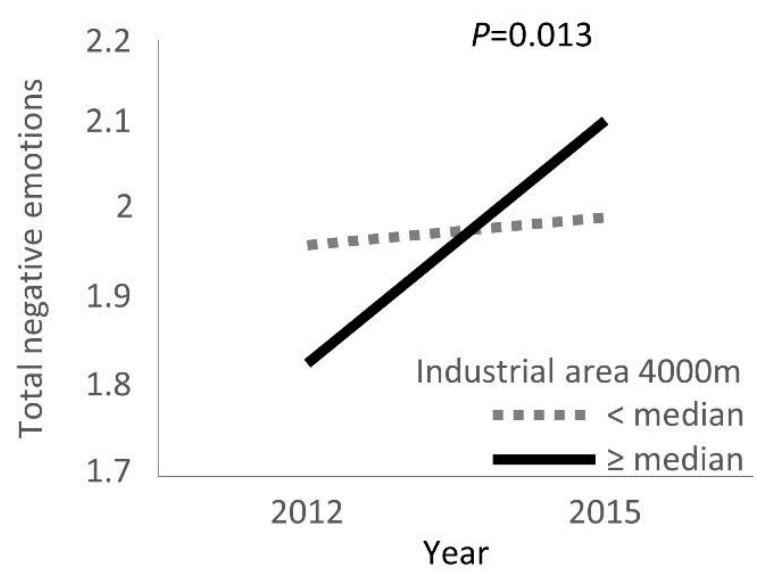

C

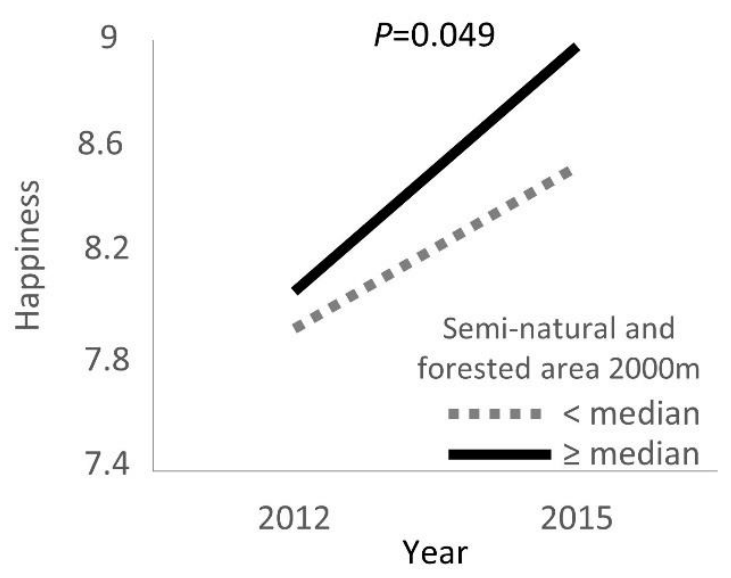


Figure 3. Models assessing the role of noise and air pollution on the cross-sectional relationship between residential landscape and stress-related parameters. The basic linear regression model is adjusted for age, sex, and socioeconomic status; the other models are additionally adjusted for noise, black carbon, or particulate matter (PM2.5).

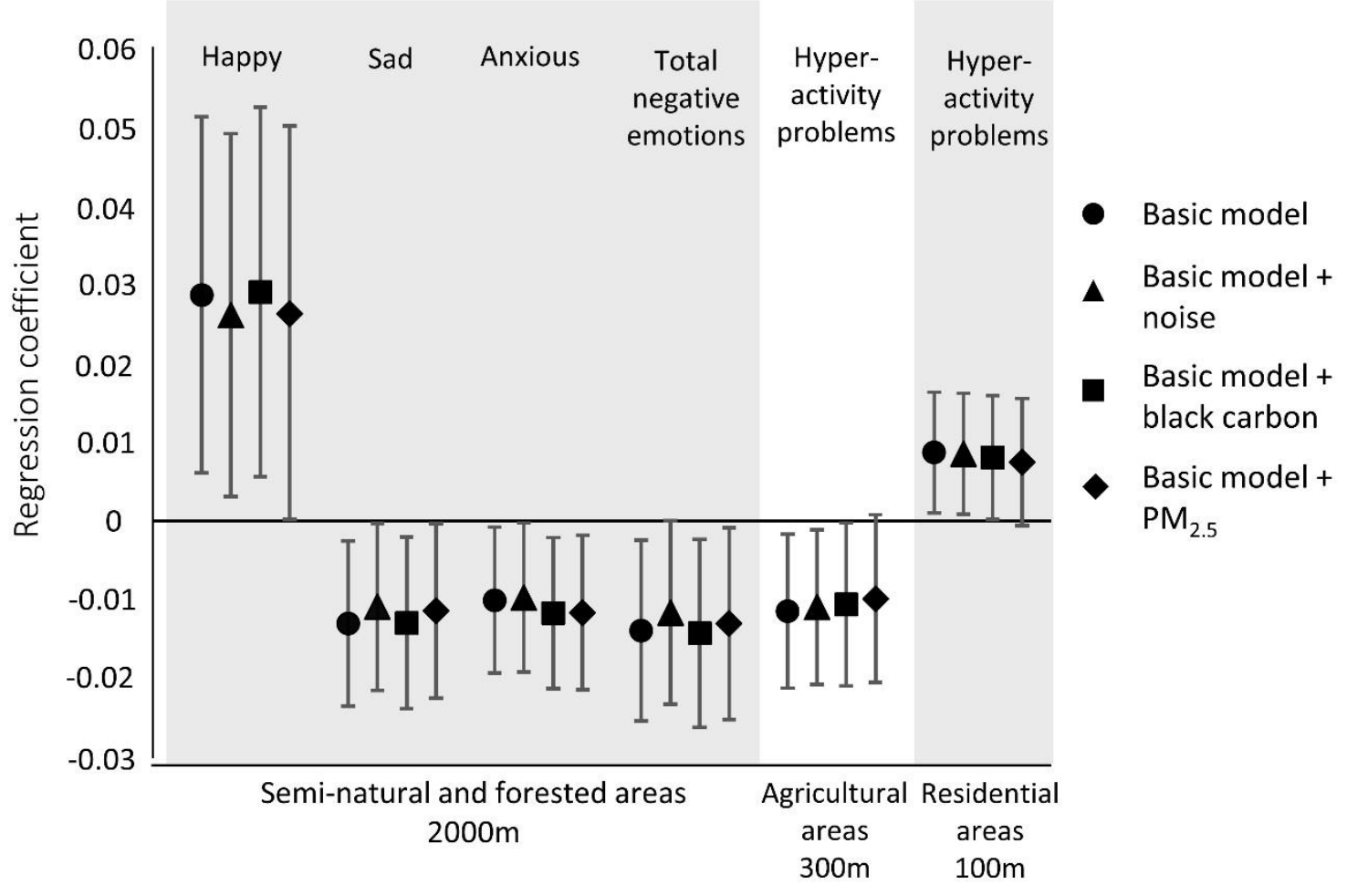




\section{Residential landscape as a predictor of psychosocial stress in the life course} from childhood to adolescence

44

Carola J.C. Van Aart, Nathalie Michels, Isabelle Sioen, Annelies De Decker, Esmee M. Bijnens, Bram G. Janssen, Stefaan De Henauw, Tim S. Nawrot

Table S1. Partial correlation coefficients between residential landscape variables and psychosocial stress parameters.

Table S2. Estimated change in stress parameters per interquartile range increase in land-use indicator (given for $\mathrm{p}<0.10$ ).

Table S3. Unadjusted correlation coefficients between residential landscape and noise and air 56 pollution.

57

Table S4. Unadjusted correlation coefficients between psychosocial stress and noise and air pollution. 59

Table S5. Detailed table of the data presented in Figure 3. Regression models assessing the role of noise and air pollution on the cross-sectional relationship between residential landscape and stressrelated parameters. The basic linear regression model is adjusted for age, sex, and socioeconomic status; the other models are additionally adjusted for noise, black carbon, or particulate matter $\left(\mathrm{PM}_{2.5}\right)$. 64

Figure S1. Location of study participants and the distribution of land-use indictors in this geographical area. Dark blue dots represent study participants, and red lines represent major motorways or main roads. 


\begin{tabular}{|c|c|c|c|c|c|c|c|c|c|c|c|c|c|c|c|c|c|c|c|c|c|}
\hline Age & Sex & Happy & Sad & Anxious & Angry & $\begin{array}{l}\text { Negative } \\
\text { emotion }\end{array}$ & $\begin{array}{c}\text { SDQ: } \\
\text { difficulties }\end{array}$ & $\begin{array}{l}\text { SDQ: } \\
\text { hyper- } \\
\text { activity }\end{array}$ & $\begin{array}{c}\text { SDQ: } \\
\text { emotional }\end{array}$ & $\begin{array}{l}\text { SDQ: } \\
\text { pro- } \\
\text { social }\end{array}$ & $\begin{array}{l}\text { SDQ: } \\
\text { conduct }\end{array}$ & $\begin{array}{l}\text { SDQ: } \\
\text { peer }\end{array}$ & $\begin{array}{c}\text { Hair } \\
\text { cortisol }\end{array}$ & $\begin{array}{c}\text { Natural } \\
\text { areas } \\
2000 \mathrm{~m}\end{array}$ & $\begin{array}{l}\text { Agricul- } \\
\text { tural } \\
\text { areas } \\
300 \mathrm{~m}\end{array}$ & $\begin{array}{c}\text { Residen- } \\
\text { tial area } \\
100 \mathrm{~m}\end{array}$ & $\begin{array}{c}\text { Indus- } \\
\text { trial } \\
\text { area } \\
4000 \mathrm{~m}\end{array}$ & $\begin{array}{c}\text { Major } \\
\text { road }\end{array}$ & $\begin{array}{l}\text { DWTD } \\
50 \mathrm{~m}\end{array}$ & $\begin{array}{l}\text { DWTD } \\
100 \mathrm{~m}\end{array}$ & $\begin{array}{l}\text { DWTD } \\
200 \mathrm{~m}\end{array}$ \\
\hline
\end{tabular}

\begin{tabular}{|c|c|c|c|c|c|c|c|c|c|c|c|c|c|c|c|c|c|c|c|c|c|c|c|}
\hline \multirow{3}{*}{ Sex } & & & & & & & & & & & & & & & & & $300 \mathrm{~m}$ & & $4000 \mathrm{~m}$ & & & & \\
\hline & $r$ & -0.025 & & & & & & & & & & & & & & & & & & & & & \\
\hline & $p$ & 0.714 & & & & & & & & & & & & & & & & & & & & & \\
\hline \multirow[t]{2}{*}{ Happy } & $r$ & 0.017 & -0.062 & & & & & & & & & & & & & & & & & & & & \\
\hline & $p$ & 0.801 & 0.363 & & & & & & & & & & & & & & & & & & & & \\
\hline \multirow[t]{2}{*}{ Sad } & $r$ & 0.231 & 0.158 & -0.316 & & & & & & & & & & & & & & & & & & & \\
\hline & $p$ & 0.001 & 0.019 & $<.001$ & & & & & & & & & & & & & & & & & & & \\
\hline \multirow[t]{2}{*}{ Anxious } & $r$ & 0.120 & 0.139 & -0.068 & 0.462 & & & & & & & & & & & & & & & & & & \\
\hline & $p$ & 0.077 & 0.040 & 0.318 & $<.001$ & & & & & & & & & & & & & & & & & & \\
\hline \multirow[t]{2}{*}{ Angry } & $r$ & 0.254 & 0.046 & -0.221 & 0.546 & 0.362 & & & & & & & & & & & & & & & & & \\
\hline & $p$ & 0.001 & 0.495 & 0.001 & $<.001$ & $<.001$ & & & & & & & & & & & & & & & & & \\
\hline \multirow[t]{2}{*}{ Negative emotions } & $r$ & 0.246 & 0.125 & -0.318 & 0.829 & 0.650 & 0.778 & & & & & & & & & & & & & & & & \\
\hline & $p$ & 0.001 & 0.064 & $<.001$ & $<.001$ & $<.001$ & $<.001$ & & & & & & & & & & & & & & & & \\
\hline \multirow[t]{2}{*}{ SDQ: difficulties } & $r$ & -0.004 & -0.106 & 0.015 & 0.119 & 0.096 & 0.113 & 0.128 & & & & & & & & & & & & & & & \\
\hline & $p$ & 0.948 & 0.120 & 0.821 & 0.079 & 0.158 & 0.097 & 0.059 & & & & & & & & & & & & & & & \\
\hline \multirow[t]{2}{*}{ SDQ: hyperactivity } & $r$ & -0.095 & -0.224 & 0.091 & -0.006 & 0.006 & -0.125 & -0.092 & 0.633 & & & & & & & & & & & & & & \\
\hline & $p$ & 0.162 & $<.001$ & 0.181 & 0.919 & 0.927 & 0.066 & 0.173 & $<.001$ & & & & & & & & & & & & & & \\
\hline \multirow[t]{2}{*}{ SDQ: emotional } & $r$ & 0.024 & 0.149 & -0.008 & 0.188 & 0.163 & 0.193 & 0.224 & 0.680 & 0.146 & & & & & & & & & & & & & \\
\hline & $p$ & 0.715 & 0.028 & 0.898 & 0.005 & 0.016 & 0.004 & 0.001 & $<.001$ & 0.031 & & & & & & & & & & & & & \\
\hline \multirow[t]{2}{*}{ SDQ: prosocial } & $r$ & -0.000 & 0.129 & 0.120 & -0.027 & 0.084 & -0.064 & -0.027 & -0.251 & -0.098 & 0.053 & & & & & & & & & & & & \\
\hline & $p$ & 0.998 & 0.057 & 0.078 & 0.691 & 0.217 & 0.348 & 0.688 & 0.001 & 0.147 & 0.433 & & & & & & & & & & & & \\
\hline \multirow[t]{2}{*}{ SDQ: conduct } & $r$ & 0.032 & -0.072 & 0.030 & 0.104 & 0.031 & 0.110 & 0.108 & 0.743 & 0.426 & 0.375 & -0.336 & & & & & & & & & & & \\
\hline & $p$ & 0.632 & 0.286 & 0.655 & 0.126 & 0.640 & 0.106 & 0.111 & $<.001$ & $<.001$ & $<.001$ & $<.001$ & & & & & & & & & & & \\
\hline \multirow{2}{*}{ SDQ: peer } & $r$ & 0.070 & -0.117 & -0.112 & 0.074 & 0.066 & 0.186 & 0.154 & 0.610 & 0.013 & 0.386 & -0.319 & 0.290 & & & & & & & & & & \\
\hline & $p$ & 0.302 & 0.084 & 0.099 & 0.274 & 0.329 & 0.006 & 0.023 & $<.001$ & 0.847 & $<.001$ & $<.001$ & $<.001$ & & & & & & & & & & \\
\hline \multirow[t]{2}{*}{ Hair cortisol } & $r$ & -0.035 & -0.048 & 0.032 & -0.025 & 0.075 & -0.068 & 0.007 & -0.006 & 0.079 & -0.029 & 0.017 & -0.096 & -0.027 & & & & & & & & & \\
\hline & $p$ & 0.674 & 0.558 & 0.698 & 0.755 & 0.364 & 0.414 & 0.924 & 0.938 & 0.339 & 0.719 & 0.836 & 0.245 & 0.740 & & & & & & & & & \\
\hline \multirow{2}{*}{$\begin{array}{l}\text { Natural and forested } \\
\text { areas } 2000 \mathrm{~m}\end{array}$} & $r$ & 0.026 & -0.025 & 0.152 & -0.144 & -0.124 & -0.024 & -0.131 & -0.047 & 0.061 & -0.080 & -0.043 & -0.039 & -0.111 & -0.053 & & & & & & & & \\
\hline & $p$ & 0.701 & 0.705 & 0.024 & 0.033 & 0.066 & 0.723 & 0.052 & 0.489 & 0.364 & 0.240 & 0.525 & 0.563 & 0.103 & 0.525 & & & & & & & & \\
\hline Agricultural areas & $\mathrm{r}$ & -0.004 & 0.014 & 0.027 & -0.028 & 0.073 & 0.025 & 0.031 & -0.095 & -0.191 & 0.048 & 0.087 & -0.085 & -0.024 & -0.125 & 0.020 & & & & & & & \\
\hline $300 \mathrm{~m}$ & $p$ & 0.943 & 0.830 & 0.690 & 0.680 & 0.281 & 0.705 & 0.641 & 0.162 & 0.004 & 0.480 & 0.200 & 0.211 & 0.724 & 0.132 & 0.759 & & & & & & & \\
\hline Residential area & $r$ & -0.008 & 0.009 & -0.012 & 0.017 & -0.069 & -0.037 & -0.041 & 0.138 & 0.174 & 0.042 & -0.051 & 0.102 & 0.047 & 0.162 & -0.073 & -0.853 & & & & & & \\
\hline $100 \mathrm{~m}$ & $p$ & 0.897 & 0.894 & 0.851 & 0.795 & 0.312 & 0.578 & 0.548 & 0.042 & 0.010 & 0.530 & 0.452 & 0.135 & 0.491 & 0.050 & 0.279 & $<.001$ & & & & & & \\
\hline Industrial area & $r$ & 0.105 & 0.031 & -0.049 & 0.143 & 0.039 & 0.127 & 0.148 & 0.106 & 0.114 & 0.037 & -0.088 & 0.096 & 0.035 & 0.114 & -0.207 & -0.345 & 0.249 & & & & & \\
\hline $4000 \mathrm{~m}$ & $p$ & 0.121 & 0.649 & 0.466 & 0.034 & 0.563 & 0.061 & 0.029 & 0.120 & 0.093 & 0.583 & 0.192 & 0.157 & 0.603 & 0.168 & 0.002 & $<.001$ & 0.001 & & & & & \\
\hline \multirow[t]{2}{*}{ Major road } & $r$ & 0.017 & -0.074 & 0.011 & -0.039 & 0.021 & 0.039 & 0.000 & 0.014 & 0.038 & 0.022 & 0.017 & -0.009 & -0.007 & -0.061 & 0.377 & 0.282 & -0.163 & -0.294 & & & & \\
\hline & $p$ & 0.803 & 0.272 & 0.861 & 0.568 & 0.750 & 0.560 & 0.992 & 0.827 & 0.577 & 0.745 & 0.799 & 0.890 & 0.913 & 0.458 & $<.001$ & $<.001$ & 0.016 & $<.001$ & & & & \\
\hline DWTD $50 \mathrm{~m}$ & $r$ & 0.032 & 0.026 & 0.010 & 0.017 & 0.014 & -0.047 & -0.043 & 0.047 & 0.159 & -0.055 & -0.033 & 0.059 & -0.042 & 0.022 & 0.034 & -0.162 & 0.109 & 0.204 & -0.113 & & & \\
\hline & $p$ & 0.630 & 0.698 & 0.873 & 0.796 & 0.835 & 0.488 & 0.527 & 0.486 & 0.019 & 0.415 & 0.620 & 0.385 & 0.532 & 0.790 & 0.616 & 0.017 & 0.107 & 0.002 & 0.097 & & & \\
\hline DWTD $100 \mathrm{~m}$ & $r$ & 0.079 & 0.072 & -0.001 & 0.100 & 0.045 & -0.042 & 0.007 & 0.056 & 0.124 & -0.017 & 0.006 & 0.004 & 0.005 & 0.066 & -0.068 & -0.264 & 0.202 & 0.198 & -0.438 & 0.445 & & \\
\hline & $p$ & 0.246 & 0.288 & 0.980 & 0.142 & 0.504 & 0.537 & 0.917 & 0.408 & 0.068 & 0.797 & 0.924 & 0.953 & 0.935 & 0.426 & 0.319 & $<.001$ & 0.002 & 0.003 & $<.001$ & $<.001$ & & \\
\hline DWTD $200 \mathrm{~m}$ & $r$ & 0.053 & 0.098 & 0.022 & 0.104 & 0.005 & -0.030 & 0.020 & 0.067 & 0.098 & 0.042 & -0.000 & 0.033 & -0.002 & 0.071 & -0.149 & -0.311 & 0.240 & 0.411 & -0.630 & 0.365 & 0.834 & \\
\hline & $p$ & 0.436 & 0.150 & 0.741 & 0.124 & 0.936 & 0.658 & 0.764 & 0.320 & 0.149 & 0.534 & 0.995 & 0.619 & 0.972 & 0.394 & 0.027 & $<.001$ & 0.001 & $<.001$ & $<.001$ & $<.001$ & $<.001$ & \\
\hline DWTD $300 \mathrm{~m}$ & $r$ & 0.054 & 0.096 & 0.021 & 0.106 & 0.003 & -0.032 & 0.020 & 0.070 & 0.098 & 0.044 & -0.002 & 0.038 & -0.001 & 0.069 & -0.155 & -0.313 & 0.241 & 0.418 & -0.643 & 0.360 & 0.823 & 0.998 \\
\hline & $p$ & 0.423 & 0.156 & 0.748 & 0.118 & 0.964 & 0.632 & 0.767 & 0.302 & 0.147 & 0.511 & 0.973 & 0.570 & 0.984 & 0.402 & 0.022 & $<.001$ & 0.001 & $<.001$ & $<.001$ & $<.001$ & $<.001$ & $<.001$ \\
\hline
\end{tabular}


Table S2. Estimated change in stress parameters per interquartile range increase in land-use indicator (given for $\mathrm{p}<0.10)$.

\begin{tabular}{|c|c|c|c|}
\hline Land-use indicators (interquartile range) & $\begin{array}{l}\text { Stress } \\
\text { score } \\
\text { change }\end{array}$ & $\begin{array}{c}\text { 95\% Confidence } \\
\text { interval }\end{array}$ & $p$-value \\
\hline \multicolumn{4}{|l|}{ Happiness } \\
\hline Semi-natural and forested area: 1000 m buffer (+5\%) & 0.12 & 0.02 to 0.22 & 0.02 \\
\hline 2000 m buffer $(+6 \%)$ & 0.17 & 0.04 to 0.31 & 0.01 \\
\hline Residential area: $1000 \mathrm{~m}$ buffer (+38\%) & -0.37 & -0.71 to -0.03 & 0.03 \\
\hline 2000 m buffer (+26\%) & -0.44 & -0.81 to -0.07 & 0.02 \\
\hline 3000 m buffer (+15\%) & -0.31 & -0.62 to -0.01 & 0.04 \\
\hline Industrial area: 3000 m buffer (+5\%) & -0.34 & -0.74 to 0.05 & 0.09 \\
\hline \multicolumn{4}{|l|}{$\underline{S a d n e s s}^{\mathrm{a}}$} \\
\hline Semi-natural and forested area: 1000 m buffer (+5\%) & $-6.18 \%$ & -11.63 to $-1.01 \%$ & 0.01 \\
\hline 2000 m buffer (+6\%) & $-8.33 \%$ & -15.03 to $-2.02 \%$ & 0.02 \\
\hline $3000 \mathrm{~m}$ buffer $(+6 \%)$ & $-9.52 \%$ & -20.19 to $0.20 \%$ & 0.06 \\
\hline $4000 \mathrm{~m}$ buffer $(+4 \%)$ & $-8.22 \%$ & -17.37 to $0.22 \%$ & 0.06 \\
\hline Industrial area: 2000 m buffer (+4\%) & $9.42 \%$ & 1.01 to $18.53 \%$ & 0.04 \\
\hline $3000 \mathrm{~m}$ buffer $(+5 \%)$ & $21.78 \%$ & 2.02 to $45.96 \%$ & 0.03 \\
\hline Residential area: 2000 m buffer (+26\%) & $15.86 \%$ & -2.49 to $37.58 \%$ & 0.09 \\
\hline $3000 \mathrm{~m}$ buffer $(+15 \%)$ & $14.36 \%$ & -0.87 to $31.92 \%$ & 0.07 \\
\hline 5000 m buffer (+4\%) & $5.19 \%$ & $-0.37 \%$ to $11.06 \%$ & 0.07 \\
\hline \multicolumn{4}{|l|}{$\underline{\text { Anxiousness }}^{\mathrm{a}}$} \\
\hline Semi-natural and forested area: 2000 m buffer (+6\%) & $-6.19 \%$ & -12.75 to $-0.46 \%$ & 0.03 \\
\hline 3000 m buffer $(+6 \%)$ & $-11.55 \%$ & -20.92 to $-3.25 \%$ & 0.01 \\
\hline $4000 \mathrm{~m}$ buffer $(+4 \%)$ & $-9.65 \%$ & -16.77 to $-2.13 \%$ & 0.01 \\
\hline $5000 \mathrm{~m}$ buffer $(+6 \%)$ & $-11.92 \%$ & -25.97 to $0.56 \%$ & 0.06 \\
\hline \multicolumn{4}{|l|}{$\underline{\text { Total negative emotions }}^{\text {a }}$} \\
\hline Semi-natural and forested area: 1000 m buffer (+5\%) & $-6.80 \%$ & -12.31 to $-1.56 \%$ & 0.01 \\
\hline 2000 m buffer (+6\%) & $-8.66 \%$ & -16.39 to $-1.45 \%$ & 0.02 \\
\hline $3000 \mathrm{~m}$ buffer $(+6 \%)$ & $-10.90 \%$ & -22.79 to $-0.17 \%$ & 0.05 \\
\hline 4000 m buffer $(+4 \%)$ & $-9.87 \%$ & -20.08 to $-0.53 \%$ & 0.04 \\
\hline Industrial area: 2000 m buffer (+4\%) & $8.58 \%$ & -1.04 to $19.13 \%$ & 0.08 \\
\hline $3000 \mathrm{~m}$ buffer $(+5 \%)$ & $18.34 \%$ & -3.14 to $44.44 \%$ & 0.09 \\
\hline \multicolumn{4}{|l|}{$\underline{\text { Conduct problems }}^{\mathrm{a}}$} \\
\hline Semi-natural and forested area: 3000 m buffer (+6\%) & $-7.42 \%$ & -15.78 to $0.33 \%$ & 0.06 \\
\hline $4000 \mathrm{~m}$ buffer $(+4 \%)$ & $-7.23 \%$ & -14.38 to $-0.53 \%$ & 0.03 \\
\hline 5000 m buffer $(+6 \%)$ & $-10.44 \%$ & -22.84 to $0.71 \%$ & 0.07 \\
\hline Agricultural area: 100 m buffer (+53\%) & $-9.75 \%$ & -21.80 to $1.13 \%$ & 0.08 \\
\hline Industrial area: 2000 m buffer (+4\%) & $6.13 \%$ & -0.66 to $13.38 \%$ & 0.08 \\
\hline 3000 m buffer $(+5 \%)$ & $16.10 \%$ & 0.71 to $33.84 \%$ & 0.04 \\
\hline Residential area: 300 m buffer (+45\%) & $10.29 \%$ & -1.03 to $22.89 \%$ & 0.08 \\
\hline $4000 \mathrm{~m}$ buffer $(+8 \%)$ & $7.27 \%$ & -0.34 to $15.46 \%$ & 0.06 \\
\hline $5000 \mathrm{~m}$ buffer $(+4 \%)$ & $5.15 \%$ & 0.77 to $9.72 \%$ & 0.02 \\
\hline
\end{tabular}


Hyperactivity problems

Agricultural area: $100 \mathrm{~m}$ buffer ( $+53 \%)$

$\begin{array}{lll}-0.41 & -0.82 \text { to } 0.00 & 0.05\end{array}$

$300 \mathrm{~m}$ buffer $(+44 \%)$

$-0.50$

0.02

$500 \mathrm{~m}$ buffer $(+36 \%)$

$-0.40$

-0.93 to -0.07

0.05

$3000 \mathrm{~m}$ buffer $(+36 \%)$

$-0.36$

-0.81 to 0.00

0.09

Residential area: $100 \mathrm{~m}$ buffer $(+55 \%)$

0.48

-0.77 to 0.05

0.03

$300 \mathrm{~m}$ buffer $(+45 \%)$

0.61

0.06 to 0.90

$<0.01$

$500 \mathrm{~m}$ buffer $(+37 \%)$

0.51

0.19 to 1.04

0.01

Peer problems $^{\mathrm{a}}$

Semi-natural and forested area: $3000 \mathrm{~m}$ buffer $(+6 \%)$

$-10.00 \%$

-19.87 to $-0.94 \%$

0.03

Industrial area: $2000 \mathrm{~m}$ buffer (+4\%)

$8.19 \%$

0.28 to $16.72 \%$

0.04

Total difficulties score

Industrial area: $2000 \mathrm{~m}$ buffer (+4\%)

$0.68 \quad 0.09$ to 1.28

0.03

$3000 \mathrm{~m}$ buffer $(+5 \%)$

1.13

-0.16 to 2.43

0.09

\section{Prosocial behavior}

Industrial area: $2000 \mathrm{~m}$ buffer (+4\%)

$-0.24 \quad-0.44$ to -0.03

0.02

$3000 \mathrm{~m}$ buffer $(+5 \%)$

$-0.48$

-0.92 to -0.04

0.03

Hair cortisol $^{\text {a }}$

Agricultural area: $100 \mathrm{~m}$ buffer (+53\%)

$-16.01 \% \quad-32.39$ to $-1.66 \%$

0.03

$2000 \mathrm{~m}$ buffer $(+21 \%)$

$-12.87 \%$

-29.00 to $1.25 \%$

0.08

$3000 \mathrm{~m}$ buffer $(+17 \%)$

$-13.72 \%$

-32.07 to $2.13 \%$

0.09

Residential area: $2000 \mathrm{~m}$ buffer (+26\%)

$20.81 \% \quad-0.09$ to $46.10 \%$

0.05

${ }^{a}$ Log transformed variables, therefore estimated change should be interpreted in $\%$

Models adjusted for age, sex and parental socioeconomic status 
Table S3. Unadjusted correlation coefficients between residential landscape and noise and air pollution.

70

\begin{tabular}{|c|c|c|c|c|c|c|c|c|c|}
\hline & $\begin{array}{l}\text { Natural and } \\
\text { forested areas } \\
2000 \mathrm{~m}^{\mathrm{a}}\end{array}$ & $\begin{array}{l}\text { Agricultural } \\
\text { areas } \\
300 \mathrm{~m}^{\mathrm{a}}\end{array}$ & $\begin{array}{l}\text { Residential } \\
\text { areas } \\
100 \mathrm{~m}^{\mathrm{a}}\end{array}$ & $\begin{array}{l}\text { Industrial } \\
\text { areas } \\
4000 \mathrm{~m}^{\mathrm{a}}\end{array}$ & $\begin{array}{l}\text { Distance to } \\
\text { major road }\end{array}$ & $\begin{array}{l}\text { DWTD } \\
50 \mathrm{~m}\end{array}$ & $\begin{array}{l}\text { DWTD } \\
100 \mathrm{~m}\end{array}$ & $\begin{array}{l}\text { DWTD } \\
200 \mathrm{~m}\end{array}$ & $\begin{array}{l}\text { DWTD }_{71} \\
300 \mathrm{~m} \\
72\end{array}$ \\
\hline Noise & $-0.189 * *$ & -0.062 & 0.005 & $0.206 * *$ & $-0.474 * * *$ & 0.119 & $0.232 * * *$ & $0.338 * * *$ & 0.346 当3* \\
\hline Black Carbon & $-0.321 * * *$ & $-0.369 * * *$ & $0.207^{* *}$ & $0.611^{* * *}$ & $-0.703 * * *$ & $0.137^{*}$ & $0.311 * * *$ & $0.424 * * *$ & $0.433 * * *$ \\
\hline $\mathrm{PM}_{2.5}$ & $-0.151^{*}$ & $-0.388 * * *$ & $0.248 * * *$ & $0.756 * * *$ & $-0.396 * * *$ & 0.049 & $0.233 * * *$ & $0.332 * * *$ & $0.416^{* * *}$ \\
\hline \multicolumn{9}{|c|}{$\begin{array}{l}\text { Abbreviations: DWTD, Distance weighted traffic density; PM, particulate matter } \\
*<0.05, * *<0.01, * * *<0.001\end{array}$} & 75 \\
\hline
\end{tabular}


Table S4. Unadjusted correlation coefficients between psychosocial stress and noise and air pollution.

\begin{tabular}{|c|c|c|c|c|c|c|c|c|c|c|c|}
\hline & Happy & Sad & Anxious & Angry & $\begin{array}{l}\text { Negative } \\
\text { emotion }\end{array}$ & $\begin{array}{l}\text { SDQ: } \\
\text { difficulties }\end{array}$ & $\begin{array}{l}\text { SDQ: } \\
\text { hyperactivity }\end{array}$ & $\begin{array}{l}\text { SDQ: } \\
\text { emotional }\end{array}$ & $\begin{array}{l}\text { SDQ: } \\
\text { prosocial }\end{array}$ & $\begin{array}{l}\text { SDQ: } \\
\text { conduct }\end{array}$ & $\begin{array}{l}\text { SDQ: } \\
\text { peer }\end{array}$ \\
\hline Noise & -0.128 & $0.190 * *$ & 0.051 & $0.145 *$ & $0.172 * *$ & 0.104 & 0.082 & 0.070 & -0.044 & 0.065 & 0.122 \\
\hline Black Carbon & -0.124 & 0.113 & 0.019 & 0.070 & 0.113 & 0.034 & 0.046 & 0.024 & -0.021 & 0.032 & -0.002 \\
\hline $\mathrm{PM}_{2.5}$ & -0.104 & $0.139 *$ & 0.021 & 0.068 & 0.120 & 0.062 & 0.073 & -0.004 & -0.032 & 0.069 & 0.063 \\
\hline
\end{tabular}

Abbreviations: SDQ, Strength and Difficulties Questionnaire; PM, particulate matter

$*<0.05, * *<0.01, * * *<0.001$ 
Table S5. Detailed table of the data presented in Figure 3. Regression models assessing the role of noise and air pollution on the cross-sectional relationship between residential landscape and stress-related parameters. The basic linear regression model is adjusted for age, sex, and socioeconomic status; the other models are additionally adjusted for noise, black carbon, or particulate matter (PM2.5).

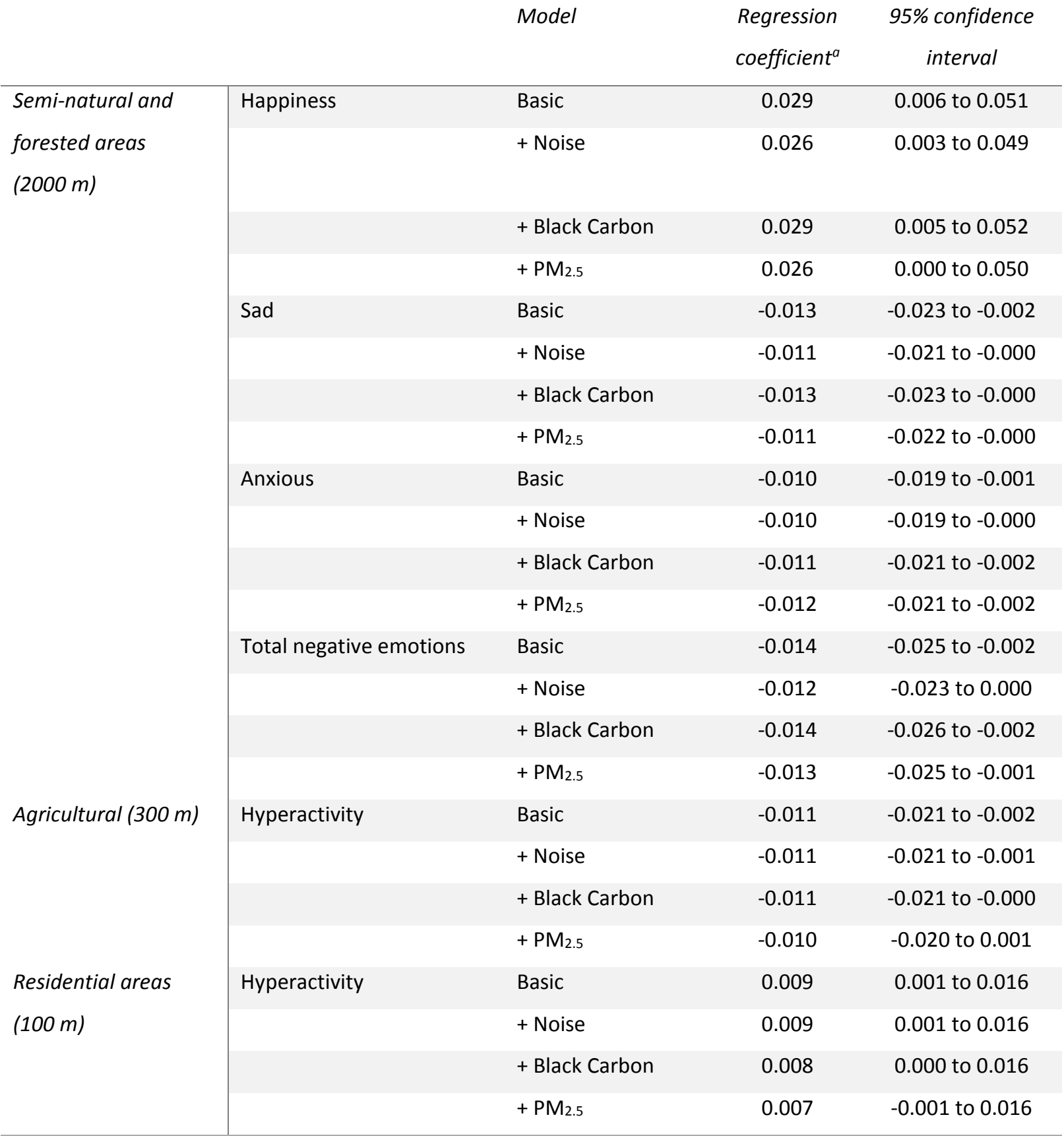

a Unstandardized regression coefficients 
84

85

86

87

88

89

90

91

92

Figure S1. Location of study participants and the distribution of land-use indictors in this geographical area. Dark blue dots represent study participants. and red lines represent major motorways or main roads.
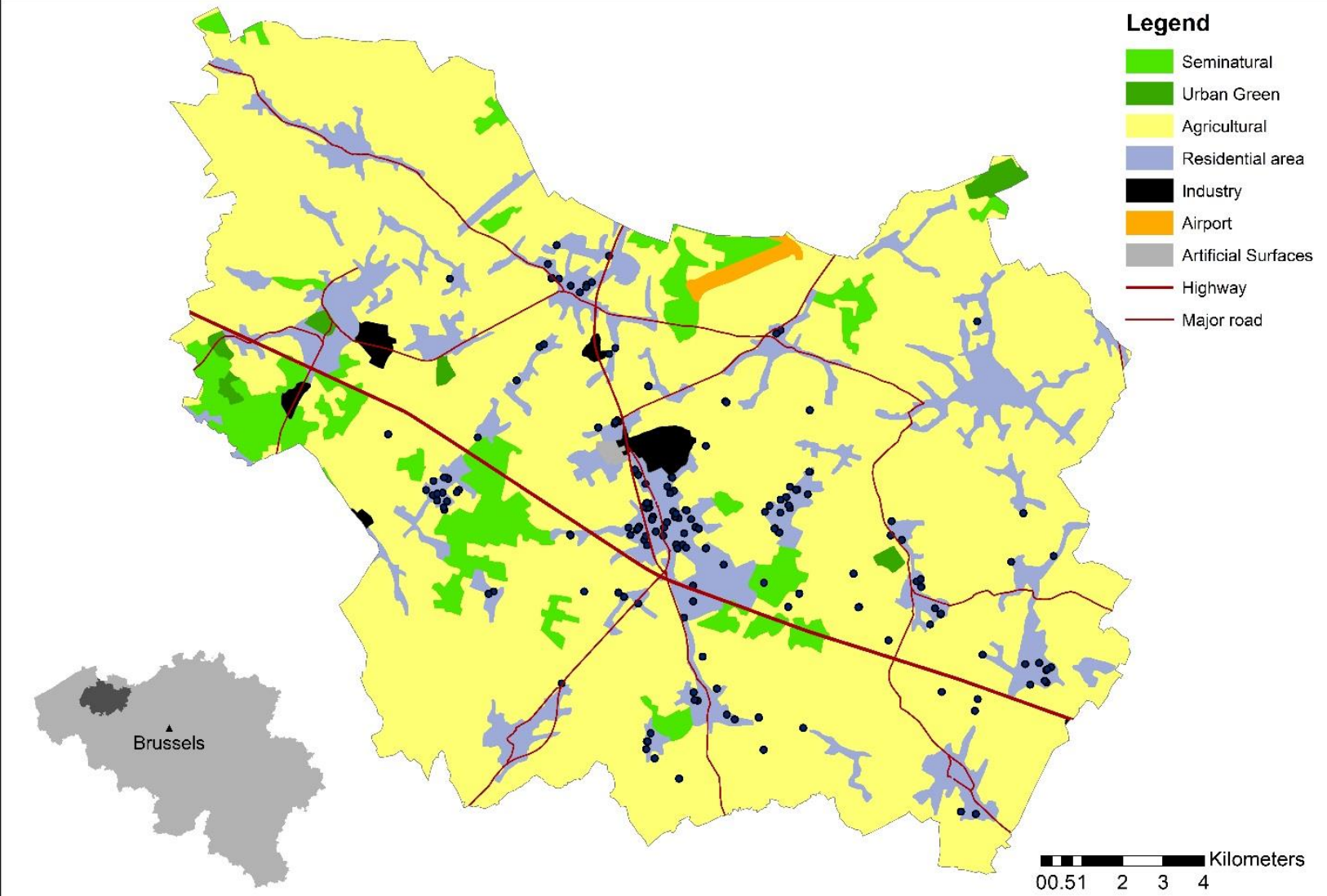